\title{
Mitochondrial acclimation potential to ocean acidification and warming of Polar cod (Boreogadus saida) and Atlantic cod (Gadus morhua)
}

Elettra Leo ${ }^{1,2}$, Kristina L. Kunz ${ }^{1,2,3}$, Matthias Schmidt ${ }^{1,2}$, Daniela Storch ${ }^{1}$, Hans-O. Pörtner ${ }^{1,2}$ and Felix C. Mark ${ }^{1 *}$

\begin{abstract}
Background: Ocean acidification and warming are happening fast in the Arctic but little is known about the effects of ocean acidification and warming on the physiological performance and survival of Arctic fish.

Results: In this study we investigated the metabolic background of performance through analyses of cardiac mitochondrial function in response to control and elevated water temperatures and $P \mathrm{CO}_{2}$ of two gadoid fish species, Polar cod (Boreogadus saida), an endemic Arctic species, and Atlantic cod (Gadus morhua), which is a temperate to cold eurytherm and currently expanding into Arctic waters in the wake of ocean warming. We studied their responses to the above-mentioned drivers and their acclimation potential through analysing the cardiac mitochondrial function in permeabilised cardiac muscle fibres after 4 months of incubation at different temperatures (Polar cod: $0,3,6,8{ }^{\circ} \mathrm{C}$ and Atlantic cod: $3,8,12,16{ }^{\circ} \mathrm{C}$ ), combined with exposure to present

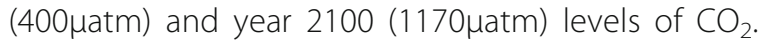

OXPHOS, proton leak and ATP production efficiency in Polar cod were similar in the groups acclimated at $400 \mu a t m$ and $1170 \mu$ atm of $\mathrm{CO}_{2}$, while incubation at $8{ }^{\circ} \mathrm{C}$ evoked increased proton leak resulting in decreased ATP production efficiency and decreased Complex IV capacity. In contrast, OXPHOS of Atlantic cod increased with temperature without compromising the ATP production efficiency, whereas the combination of high temperature and high $\mathrm{PCO}_{2}$ depressed OXPHOS and ATP production efficiency.
\end{abstract}

Conclusions: Polar cod mitochondrial efficiency decreased at $8{ }^{\circ} \mathrm{C}$ while Atlantic cod mitochondria were more resilient to elevated temperature; however, this resilience was constrained by high $\mathrm{PCO}_{2}$. In line with its lower habitat temperature and higher degree of stenothermy, Polar cod has a lower acclimation potential to warming than Atlantic cod.

Keywords: Arctic fish, RCP 8.5, Heart mitochondria, Mitochondrial capacity, Proton leak

\section{Background}

Ocean warming driven by anthropogenic $\mathrm{CO}_{2}$ emissions influences the distribution of marine animals causing significant impacts on biodiversity and ecosystem structure [1,2], such as local extinctions [3] and poleward migrations [4-6]. Fish (and other ectotherms) are particularly sensitive to fluctuations in temperature since their body temperature is in equilibrium with their

\footnotetext{
* Correspondence: Felix.Christopher.Mark@awi.de

${ }^{1}$ Alfred Wegener Institute, Helmholtz Centre for Polar and Marine Research, Integrative Ecophysiology, Am Handelshafen 12, D-27570 Bremerhaven, Germany

Full list of author information is available at the end of the article
}

environmental temperature [7]. Fish species distribution, in fact, is confined to a specific temperature window, due to the temperature dependency of physiological processes and to sustain maximal energy efficiency ([8] for review).

The increased $\mathrm{CO}_{2}$ concentration in the atmosphere is one of the major causes for the global greenhouse effect and also causes a decrease in ocean $\mathrm{pH}$, a phenomenon commonly known as ocean acidification [9]. High $\mathrm{CO}_{2}$ partial pressure $\left(\mathrm{PCO}_{2}\right)$ is known to affect biological and physiological processes of marine organisms (e.g. [10-14]) and tolerances towards other stressors [15-17]. Moreover, high $\mathrm{PCO}_{2}$ could provoke a narrowing of the thermal 
tolerance window of ectotherms, so that limits of its thermal acclimation capacity are met earlier [2, 18-21].

At the cellular level, exposure to high temperature can cause changes in the three dimensional structures of proteins, including the assembly states of multiprotein complexes and eventually protein denaturation and loss of activity [7]. Moreover, increasing temperatures can alter the cellular membranes packing order, which can cause changes in membrane-associated processes until a potential complete loss of function [22]. Furthermore, since cellular oxygen demand increases with increasing temperature, the production of mitochondrial reactive oxygen species (ROS) is likely to increase which can damage biological molecules, including lipids, proteins and DNA [23, 24]. Therefore, towards the upper limit of the thermal window, the cellular energetic costs for maintenance rise, increasing baseline energy turnover and allowing only for time-limited periods of passive tolerance. If high temperature persists over this period of passive tolerance, the costs of maintenance can only be covered at the expense of other functions such as growth and reproduction, decreasing the overall animal fitness [17]. Therefore, in light of ongoing ocean acidification and warming it is important to understand how fish respond to increasing habitat temperatures, their ability to adjust their thermal sensitivity and the role that high $P \mathrm{CO}_{2}$ plays in thermal acclimation $[2,25]$.

The fish heart is highly aerobic and sensitive to temperature [26, 27]. Its capacity limits have been hypothesized to shape the warming-induced onset of sublethal thermal constraints in fishes [2, 28-31]. Recent studies have shown that high temperature leads to heart failure in various fish species like New Zealand triplefins and temperate and tropical wrasses [28, 29, 32, 33]. It was suggested that progressive impairment of several components of the mitochondrial function measured in permeabilised heart muscle fibres, such as oxidative phosphorylation (OXPHOS, respiratory state III), ATP production efficiency and the capacity of single complexes of the Electron Transport System (ETS) shape the temperature of heart failure $\left(\mathrm{T}_{\mathrm{HF}}\right)$. High temperature changes the fluidity of mitochondrial membranes, which can entail increased proton leak through the inner membrane ([19] for review), resulting in decreased coupling ratios and causing decreased membrane potential $[34,35]$ and, as a consequence, inhibit the electrogenic transport of substrates, i. e. the transport of charged substrates like glutamate and malate that leads to the translocation of net charge across the membrane [36]. This indicates that mitochondrial metabolism is involved in functional constraints and thermal limitation of this tissue [28, 29, 32, 33]. Therefore, alterations in cardiac mitochondrial metabolism might lead to impaired cardiac energy turnover and, as a consequence, constraints in cardiac performance and ultimately affect the fishes' thermal sensitivity.

Although an extensive literature has been produced on the effects of temperature on fish cellular metabolism and mitochondrial function (e.g. $[8,33,37]$ and the literature therein), only few studies have addressed the effects of moderately elevated $\mathrm{PCO}_{2}$ on them [30, 38-41]. Moreover, as ocean warming and ocean acidification caused by high $\mathrm{PCO}_{2}$ are two sides of the same coin, they must be considered in combination in order to draw ecologically realistic conclusions $[17,42,43]$.

Ocean acidification and warming trends are projected to exert particularly strong effects in the Arctic. As one of the consequences, temperate species may become established in Arctic habitats (by poleward migration), potentially displacing resident taxa $[1,4,6]$. For example, in the past decade the Northeast Arctic population of Atlantic cod (Gadus morhua, NEAC) has expanded its range into the Barents Sea $[44,45]$, on the North-east Greenland shelf [46] and in the coastal waters around Svalbard, which are inhabited by native Polar cod (Boreogadus saida), a key species in this region $[1,47]$.

Polar cod is a permanently cold adapted Arctic fish (thermal habitat around Svalbard ranging from -2 to $\left.+7{ }^{\circ} \mathrm{C}[48,49]\right)$ while NEAC is a cold acclimated subArctic population of temperate Atlantic cod expanding into the Arctic (habitat thermal range around Svalbard: $\left.0-8{ }^{\circ} \mathrm{C}[1,50]\right)$. Cold-acclimated and -adapted fish are known to have elevated mitochondrial densities. Among cold adapted species, extreme stenotherms such as high Antarctic fish, have high densities but low mitochondrial capacities and low proton leak in aerobic tissues [37, 51-53]. This may result in the low maintenance costs derived by proton leak and narrow thermal windows of these species and, as a consequence, cause high sensitivity to ocean warming [53, 54]. On the other hand, eurythermal cold adaptation ensures mitochondrial function over a wider range of temperatures at lower mitochondrial densities and maximized capacities [53, 55]. As a permanently cold adapted fish, Polar cod may therefore not be able to adjust mitochondrial capacities during warming to a similar extent as NEAC, which apparently has a higher capacity to adjust to higher temperatures by decreasing mitochondrial densities and capacities and thereby developing the metabolic plasticity necessary to acclimate to new conditions [56]. The differences in thermal response and, in particular, the ability to acclimate to higher temperatures will play a central role for their interaction in a changing ecosystem.

Hence, the aim of this study was to investigate the acclimation potential of Polar cod Boreogadus saida and Northeast Arctic cod (NEAC) Gadus morhua exposed to water temperatures and $\mathrm{PCO}_{2}$ projected for 
the year 2100 in the Arctic i.e. $8{ }^{\circ} \mathrm{C}$ and $1170 \mu$ atm $\mathrm{PCO}_{2}$ (RCP 8.5 [57]). For a deeper understanding of the impact of ocean acidification and warming on the bioenergetics of the two species in relation to thermal tolerance, we further investigated mitochondrial function in the cardiac muscle of animals incubated for 4 months at four different temperatures (Polar cod: 0, 3, 6, $8{ }^{\circ} \mathrm{C}$ and Atlantic cod: $3,8,12,16{ }^{\circ} \mathrm{C}$ ), and two $\mathrm{PCO}_{2}(400 \mu \mathrm{atm}$ and $1170 \mu \mathrm{atm})$ in a cross factorial design. We used permeabilised cardiac muscle fibres to investigate a system resembling the living state as closely as possible [58-60], facilitating the extrapolation from measurements of cardiac mitochondrial capacities to their potential effects on the heart and eventually drawing conclusions on the effects of high temperature and high $\mathrm{PCO}_{2}$ on the whole organism. Moreover, by analysing the mitochondrial function at the respective incubation temperature we could investigate the acclimation potential of the two species. We hypothesized that NEAC had higher thermal limits and a larger acclimation capacity than Polar cod and found accordingly that mitochondrial functions are constrained at lower temperatures in Polar cod than in NEAC. We discuss our results in light of the findings reported by Kunz et al. [61], who showed wider thermal windows for growth and standard metabolic rate (SMR) in NEAC than in Polar cod from the same acclimation experiment.

\section{Methods}

\section{Animal collection}

Juvenile Polar cod were collected by bottom trawl in combination with a fish lift [62] on January $17^{\text {th }}, 2013$ from the inner part of Kongsfjorden (Svalbard, $78^{\circ} 97^{\prime} \mathrm{N}$ $\left.12^{\circ} 51^{\prime} \mathrm{E}\right)$ at $120 \mathrm{~m}$ depth and a water temperature between 2 and $3{ }^{\circ} \mathrm{C}$. They were kept at $3.3-3.8^{\circ} \mathrm{C}$ in the facilities of the Tromsø Aquaculture Research Station, in Kårvik (Norway) until late April 2013 when they were transported to the aquarium facilities of the Alfred Wegener Institute (AWI) in Bremerhaven (Germany), where they were kept at $5{ }^{\circ} \mathrm{C}, 32 \mathrm{PSU}$ and ambient $\mathrm{PCO}_{2}$ until the start of the incubation.

Juvenile Northeast Arctic cod (NEAC) were caught in late August 2013 in several locations off Western Svalbard during RV Heincke cruise HE408 in Rijpfjorden $\left(80^{\circ} 15.42^{\prime} \mathrm{N} 22^{\circ} 12.89^{\prime} \mathrm{E}\right)$, Hinlopenstretet $\left(79^{\circ} 30.19^{\prime} \mathrm{N}\right.$ $18^{\circ} 57.51^{\prime} \mathrm{E}$ ), and Forlandsundet ( $78^{\circ} 54.60^{\prime} \mathrm{N} 11^{\circ} 3.66^{\prime}$ E) at $0-40 \mathrm{~m}$ depth and water temperatures between 3.5 and $5.5{ }^{\circ} \mathrm{C}$ using a pelagic midwater trawl in combination with a fish lift [62]. The specimens were transported to the AWI facilities in Bremerhaven (Germany), where they were kept at $5{ }^{\circ} \mathrm{C}, 32$ PSU and ambient $\mathrm{PCO}_{2}$ until the start of the incubation.

\section{Incubation}

Polar cod incubation started in June 2013 and of NEAC in May 2014. After at least 4 weeks of acclimation to laboratory conditions $\left(5{ }^{\circ} \mathrm{C}, 32 \mathrm{PSU}\right.$ and ambient $\left.\mathrm{PCO}_{2}\right)$, individuals from both species were housed in single tanks and randomly allocated to the temperature and $P \mathrm{CO}_{2}$ incubation set-up with a $12 \mathrm{~h}$ day/night rhythm. The respective $P \mathrm{CO}_{2}$ conditions were pre-adjusted in a header tank containing 2001 of seawater. Virtually $\mathrm{CO}_{2}$-free pressurized air and pure $\mathrm{CO}_{2}$ were mixed by means of mass flow controllers (4 and 6 channel MFC system, HTK, Hamburg, Germany) to achieve the desired $\mathrm{PCO}_{2}$. Temperature was adjusted by $1{ }^{\circ} \mathrm{C}$ per day for each group starting from $5{ }^{\circ} \mathrm{C} . \mathrm{PCO}_{2}$ in the high $\mathrm{PCO}_{2}$ group was adjusted within 1 day after the incubation temperature was reached. The animals were kept under incubation conditions for 4 months and fed ad libitum with commercial pellet feed (Amber Neptun, $5 \mathrm{~mm}$, Skretting AS, Norway) every fourth day [61]. The sampling of Polar cod and NEAC took place after 4 days of fasting, due to sampling and experimental logistics three to six individuals of Polar cod and four to eight individuals of NEAC were sampled in one batch. Because of a failure in the power supply the group incubated at $3{ }^{\circ} \mathrm{C}$ and high $\mathrm{PCO}_{2}$ died before the mitochondrial capacity could be investigated.

Average length and weight, as well as the number of the specimens per treatment at the time of sampling are given in Table 1.

\section{$\mathrm{CO}_{2}$ and carbonate chemistry}

Temperature, salinity, DIC and pH (total scale) were measured once to twice a week in triplicates in order to monitor the seawater chemistry of the incubation. Temperature and salinity were measured with a WTW LF 197 multimeter (WTW, Weilheim, Germany). pH was measured with a $\mathrm{pH}$ meter (pH 3310, WTW, Weilheim, Germany) calibrated with thermally equilibrated NBS-buffers (2-point-calibration). The $\mathrm{pH}$-values were then corrected to $\mathrm{pH}$ Total scale using $\mathrm{pH}$-defined Tris-Buffer (Batch 4, Marine Physical Laboratory, University of California, San Diego, CA, USA).

DIC was measured by a Seal QuAAtro SFA Analyzer (800 TM, Seal Analytical, Mequon, United States of America). Calculations of the carbonate system were conducted using CO2sys [63], applying the K1, K2 constants after Mehrbach et al. [64], refitted after Dickson and Millero [65] and using KHSO4 dissociation constants after Dickson [66] assuming a pressure of $10 \mathrm{dbar}$.

Complete summaries of the seawater parameters and raw data for both species are available from the Open Access library PANGAEA [67, 68]. 
Table 1 Total length, body weight and number of fish $(n)$ used for testing cardiac mitochondrial respiration in Polar cod (B. saida) and NEAC (G. morhua)

\begin{tabular}{|c|c|c|c|c|c|c|}
\hline \multirow[t]{3}{*}{ Acclimation } & \multicolumn{5}{|l|}{ Species } & \\
\hline & \multicolumn{3}{|l|}{ B. saida } & \multicolumn{3}{|l|}{ G. morhua } \\
\hline & Total length $(\mathrm{cm})$ & Body weight (g) & $n$ & Total length $(\mathrm{cm})$ & Body weight (g) & \\
\hline $0^{\circ} \mathrm{C}$ control & $15.28 \pm 0.37$ & $22.88 \pm 2.05$ & 5 & - & - & . \\
\hline $0{ }^{\circ} \mathrm{C}$ high & $14.30 \pm 0.64$ & $19.22 \pm 2.61$ & 6 & - & - & \\
\hline $3^{\circ} \mathrm{C}$ control & $15.62 \pm 0.98$ & $27.16 \pm 6.25$ & 3 & $20.04 \pm 0.92$ & $60.84 \pm 9.81$ & \\
\hline $3^{\circ} \mathrm{C}$ high & - & - & - & $21.61 \pm 0.46$ & $78.19 \pm 6.91$ & \\
\hline $6^{\circ} \mathrm{C}$ control & $15.73 \pm 0.21$ & $25.21 \pm 1.14$ & 6 & - & - & \\
\hline $6{ }^{\circ} \mathrm{C}$ high & $17.52 \pm 0.61$ & $32.17 \pm 2.90$ & 5 & - & - & \\
\hline $8^{\circ} \mathrm{C}$ control & $15.18 \pm 0.72$ & $20.52 \pm 2.56$ & 6 & $23.26 \pm 1.75$ & $99.04 \pm 22.13$ & \\
\hline $8^{\circ} \mathrm{C}$ high & $15.07 \pm 0.47$ & $18.76 \pm 1.11$ & 4 & $21.51 \pm 0.82$ & $80.51 \pm 10.46$ & \\
\hline $12{ }^{\circ} \mathrm{C}$ control & - & - & - & $22.70 \pm 0.80$ & $98.70 \pm 13.14$ & \\
\hline $12{ }^{\circ} \mathrm{C}$ high & - & - & - & $23.42 \pm 0.72$ & $100.75 \pm 9.22$ & \\
\hline $16^{\circ} \mathrm{C}$ control & - & - & - & $21.56 \pm 0.69$ & $81.48 \pm 9.37$ & \\
\hline $16^{\circ} \mathrm{C}$ high & - & - & - & $24.27 \pm 1.91$ & $133.13 \pm 31.87$ & \\
\hline
\end{tabular}

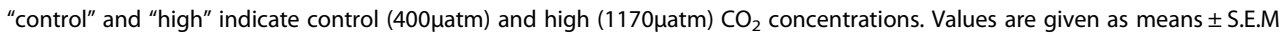

\section{Preparation of permeabilised cardiac fibres}

Fish were anaesthetized with $0.2 \mathrm{~g} \mathrm{l}^{-1}$ tricaine methane sulphonate (MS222) and killed by a spinal cut behind the head plate. Hearts were rapidly excised and washed with ice-cold modified relaxing buffer BIOPS (2.77 mM $\mathrm{CaK}_{2}$ EGTA, $7.23 \mathrm{mM} \mathrm{K}{ }_{2}$ EGTA, $5.77 \mathrm{mM} \mathrm{Na} \mathrm{N}_{2} \mathrm{ATP}$, $6.56 \mathrm{mM} \mathrm{MgCl}_{2}, 20 \mathrm{mM}$ taurine, $15 \mathrm{mM} \mathrm{Na}_{2}$-phosphocreatine, $20 \mathrm{mM}$ imidazole, $0.5 \mathrm{mM}$ dithiothreitol, $50 \mathrm{mM}$ MES, $220 \mathrm{mM}$ sucrose, $\mathrm{pH}$ 7.4, $380 \mathrm{mOsmol} \mathrm{l}^{-1}$; modified after [69]). Hearts were then separated in fibres and placed in $2 \mathrm{ml}$ ice-cold BIOPS containing $50 \mu \mathrm{g} \mathrm{ml}^{-1}$ saponin and gently shaken on ice for $20 \mathrm{~min}$. Fibres were then washed three times for $10 \mathrm{~min}$ in $2 \mathrm{ml}$ ice-cold modified mitochondrial respiration medium MIR05 (0.5 mM EGTA, $3 \mathrm{mM}$ $\mathrm{MgCl}_{2}, 60 \mathrm{mM}$ K-lactobionate, $20 \mathrm{mM}$ taurine, $10 \mathrm{mM}$ $\mathrm{KH}_{2} \mathrm{PO}_{4}, 20 \mathrm{mM}$ HEPES, $160 \mathrm{mM}$ sucrose, $1 \mathrm{~g} \mathrm{l}^{-1}$ bovine albumine serum, pH 7.4, $380 \mathrm{mOsmol}^{-1}$ ) $[29,69]$.

Directly before experimentation, a subsample of about $10 \mathrm{mg}$ fibres was blotted dry, weighed and introduced into the oxygraph sample chambers.

\section{Mitochondrial respiration}

Mitochondrial respiration was recorded using Oroboros Oxygraph-2 $\mathrm{k}^{\mathrm{TM}}$ respirometers (Oroboros Instruments, Innsbruck, Austria) and measured as weight-specific oxygen flux [pmol $\left.\mathrm{O}_{2}(\mathrm{mg} \text { fresh weight } \mathrm{sec})^{-1}\right]$ calculated in real time using Oroboros DatLab Software 5.2.1.51 (Oroboros Instruments, Innsbruck, Austria).

All analyses were performed at the respective incubation temperatures, with $c \mathrm{O}_{2}$ in a range from $\sim 370 \mathrm{nmol} \mathrm{ml}^{-1}$ (100\% air saturation) to $100 \mathrm{nmol} \mathrm{ml}{ }^{-1}$ and $P C O_{2}$ at atmospheric levels.
A substrate-uncoupler-inhibitor titration (SUIT) protocol was used on the permeabilised cardiac fibres to investigate the partial contributions of the single components of the phosphorylation system [69]). NADH - Coenzyme Q oxidoreductase (Complex I, CI) and Succinate dehydrogenase (Complex II, CII) substrates $(10 \mathrm{mM}$ glutamate, $2 \mathrm{mM}$ malate, $10 \mathrm{mM}$ pyruvate and $10 \mathrm{mM}$ succinate) were added. Saturating ADP (3 $\mathrm{mM})$ was added to stimulate oxidative phosphorylation (OXPHOS). Cytochrome c $(10 \mu \mathrm{M})$ was added to test the integrity of the outer membrane. Respiration state $\mathrm{IV}^{+}$was measured by addition of atractyloside $(0.75 \mathrm{mM})$ or oligomycin $(6 \mu \mathrm{M})$ (for Polar cod and NEAC respectively) and step-wise ( $1 \mu \mathrm{M}$ each) titration of carbonyl cyanide $p$-(trifluoromethoxy) phenylhydrazone (FCCP) was used to uncouple mitochondria (ETS). Complex I, Complex II and Coenzyme Q - cytochrome c reductase (Complex III, CIII) were inhibited by the addition of rotenone $(0.5 \mu \mathrm{M})$, malonate $(5 \mathrm{mM})$ and antimycin a $(2.5 \mu \mathrm{M})$, respectively. Lastly the activity of the Cytochrome c oxidase (Complex IV, CIV) was measured by the addition of the electron donor couple ascorbate $(2 \mathrm{mM})$ and $N, N, N^{1}, N^{1}$-tetramethyl-p-phenylenediamine (TMPD, $0.5 \mathrm{mM}$ ).

All chemicals were obtained from Sigma-Aldrich (Germany).

\section{Data analysis}

Mitochondrial respiration rates are expressed per mg fresh weight of cardiac fibres and the values are given as means \pm S.E.M. OXPHOS coupling efficiency was calculated as $\left[\left(\mathrm{OXPHOS}-\mathrm{State} \mathrm{IV}^{+}\right) \mathrm{OXPHOS}^{-1}\right]$ after Gnaiger [70]. 
Normal distribution of the data was assessed by Shapiro-Wilk test and homoscedasticity was evaluated by F-test or Bartlett test in case of two or more groups, respectively. Differences between $\mathrm{PCO}_{2}$ treatments within the same temperature treatment were evaluated by Student's $t$-test (with Welch's correction in case of non-homoscedastic data). Differences across temperatures in the same $P C \mathrm{O}_{2}$ treatment were evaluated with one-way ANOVA followed by Tukey's test for the comparison of means.

The level of statistical significance was set at $p<0.05$ for all the statistical tests.

All statistical tests were performed using $\mathrm{R}$ 3.2.0 and the "stats" package [71].

\section{Results}

The maximal oxidative phosphorylation capacity (OXPHOS) of permeabilised heart fibres of both species is shown in Fig. 1. In Polar cod, the groups incubated under control $\mathrm{PCO}_{2}$ showed significantly lower OXPHOS flux in the $0{ }^{\circ} \mathrm{C}$ acclimated fish than in all further incubation groups $\left(3{ }^{\circ} \mathrm{C}, p=0.007 ; 6{ }^{\circ} \mathrm{C}, p=0.007\right.$; $\left.8{ }^{\circ} \mathrm{C}, p=0.001\right)$. Mitochondrial respiration was at a similar level in the groups incubated at 3,6 and $8{ }^{\circ} \mathrm{C}$ $(p>0.05)$. High $\mathrm{PCO}_{2}$ levels did not affect OXPHOS, with no differences between the OXPHOS of the groups incubated at the two $P \mathrm{CO}_{2}$ levels within a temperature treatment $(p>0.05)$. The groups incubated under high $\mathrm{PCO}_{2}$ displayed fluxes that were similar at 6 and $8{ }^{\circ} \mathrm{C}(p>0.05)$ but significantly higher than in the $0{ }^{\circ} \mathrm{C}$ incubated group ( $p=0.04$, Fig. 1a).

Temperature had a significant effect on the OXPHOS of NEAC, with fluxes increasing with incubation temperature (control $\mathrm{PCO}_{2}: \mathrm{F}=4.74, p=0.02$; high
$\mathrm{PCO}_{2}: \mathrm{F}=3.78 ; p=0.02$, Fig. $\left.1 \mathrm{~b}\right)$. Moreover, the $16{ }^{\circ} \mathrm{C} /$ high $\mathrm{PCO}_{2}$ incubated group showed a lower OXPHOS compared to the $16{ }^{\circ} \mathrm{C} /$ control $P_{2}$ group $(p=0.03)$. This resulted in a more evident plateauing of OXPHOS between 12 and $16{ }^{\circ} \mathrm{C}$ in the group incubated under high $\mathrm{PCO}_{2}$. Comparing the two species, Polar cod had significantly higher OXPHOS capacities than NEAC at both $3{ }^{\circ} \mathrm{C}\left(p=0.01\right.$, Fig. 1 blue box) and $8{ }^{\circ} \mathrm{C}$ (control $P C_{2}$ : $p=0.04$; high $P \mathrm{CO}_{2}: p=0.04$, Fig. 1 red box).

In both species, state $\mathrm{IV}^{+}$was sensitive to temperature (Fig. 2): in Polar cod it remained unchanged in the groups incubated at 0,3 and $6{ }^{\circ} \mathrm{C}(p>0.05)$ but was significantly higher in animals incubated at $8{ }^{\circ} \mathrm{C}$ compared to the other incubation groups $\left(6\right.$ to $8{ }^{\circ} \mathrm{C} /$ control $P \mathrm{PO}_{2}$ : $p=0.01 ; 6$ to $8{ }^{\circ} \mathrm{C} /$ high $P \mathrm{CO}_{2}: p=0.04$ ) as shown in Fig. 2a. Quantifying State $\mathrm{IV}^{+}$as a percent fraction of OXPHOS, it was close to $20 \%$ and thus lowest in the $3{ }^{\circ} \mathrm{C}$ and $6{ }^{\circ} \mathrm{C}$ groups of $\mathrm{B}$. saida, while at 0 and $8{ }^{\circ} \mathrm{C}$ the fraction of State $\mathrm{IV}^{+}$exceeded these values about two-fold as shown in Fig. 3.

In NEAC, State $\mathrm{IV}^{+}$increased along with incubation temperature (control $\mathrm{PCO}_{2}: \mathrm{F}=5.96 ; p=0.02$, high $\left.\mathrm{PCO}_{2}: \mathrm{F}=12.43 ; p<0.001\right)$ as depicted in Fig. $2 \mathrm{~b}$, however, State $\mathrm{IV}^{+}$increased under high $\mathrm{PCO}_{2}$ at $8{ }^{\circ} \mathrm{C}$ compared to the group incubated under control $\mathrm{PCO}_{2}$ at the same temperature $(p=0.02)$. Fractional values of State $\mathrm{IV}^{+}$in OXPHOS (Fig. 3) for the groups incubated under present levels of $\mathrm{CO}_{2}$ revealed values close to $20 \%$ in the groups incubated to 3 and $8{ }^{\circ} \mathrm{C}$ and two-fold higher values after incubation to 12 and $16{ }^{\circ} \mathrm{C}$. In the groups incubated under high $\mathrm{PCO}_{2}$, State $\mathrm{IV}^{+}$of the group incubated at $8{ }^{\circ} \mathrm{C}$ showed values similar to the groups incubated to 12 and $16{ }^{\circ} \mathrm{C}$ (Fig. 3). In consequence, sensitivity to $\mathrm{CO}_{2}$ varied with incubation temperature and
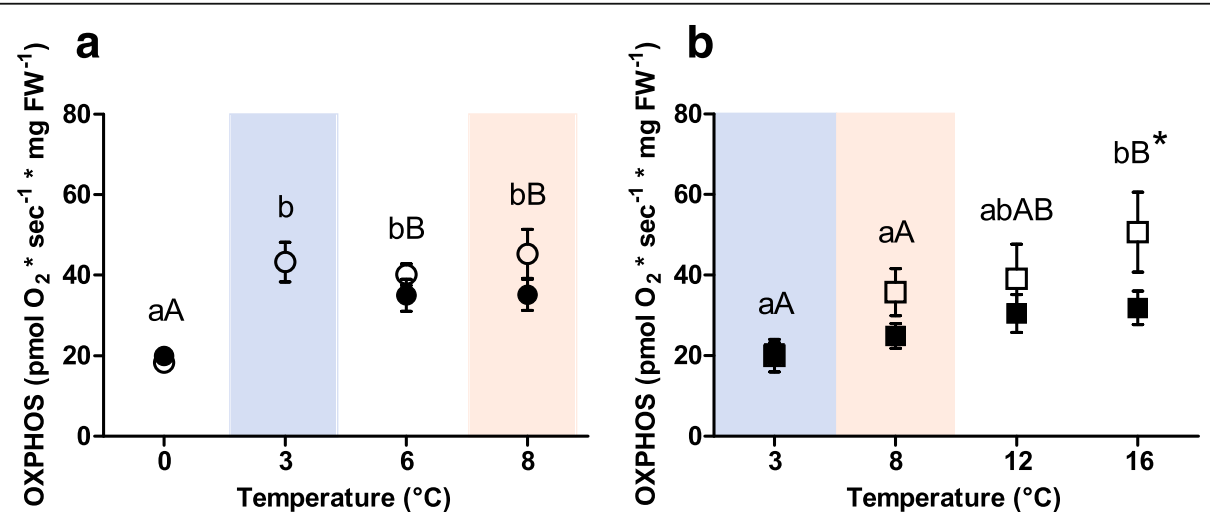

Fig. 1 Maximal oxidative phosphorylation capacity (OXPHOS) of permeabilised heart muscle fibres of (a) Polar cod (B. saida) and (b) NEAC (G. morhua). Different letters within panels indicate significant differences $(p<0.05)$ between temperature treatments; lower case letters: $\mathrm{Control} P \mathrm{CO}_{2}$

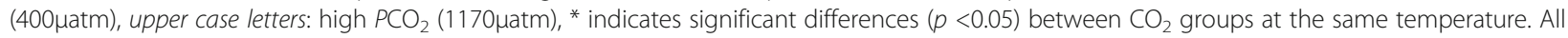

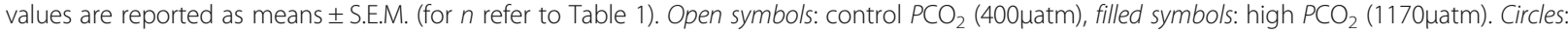
Polar cod, Squares: NEAC. Blue box: cold shared incubation temperature $\left(3^{\circ} \mathrm{C}\right)$, Red box: warm shared incubation temperature $\left(8^{\circ} \mathrm{C}\right)$ between the two species 

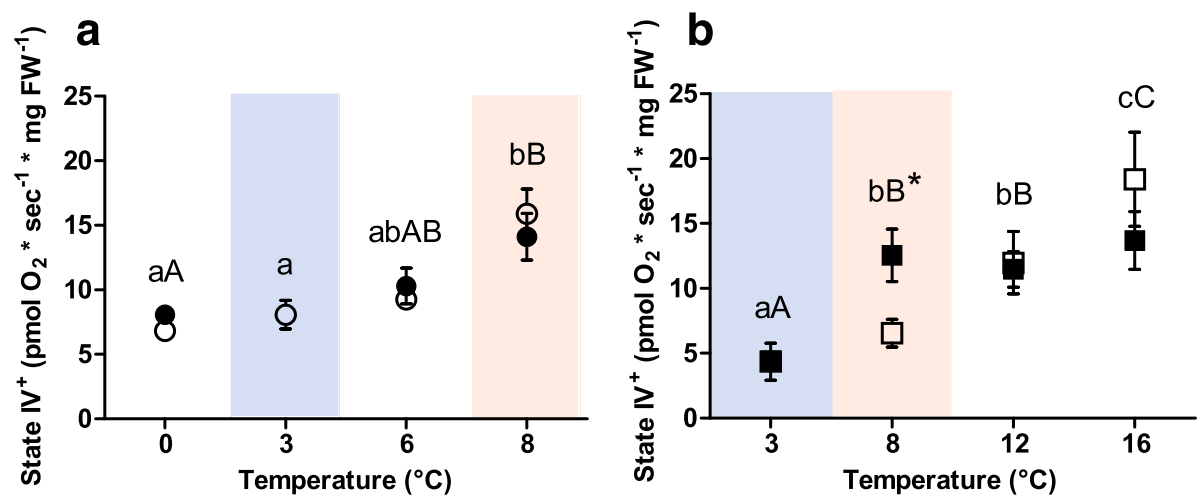

Fig. 2 State IV of permeabilised heart muscle fibres of (a) Polar cod (B. saida) and (b) NEAC (G. morhua). Different letters within panels indicate significant differences $(p<0.05)$ between temperature treatments; lower case letters: control $P \mathrm{CO}_{2}(400 \mu \mathrm{\mu tm})$, upper case letters: high $P C \mathrm{O}_{2}$ $(1170 \mu \mathrm{atm})$, * indicates significant differences $(p<0.05)$ between $\mathrm{CO}_{2}$ groups at the same temperature. All values are reported as means \pm S.E.M.

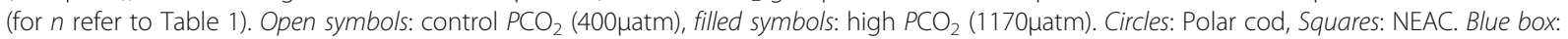
cold shared incubation temperature $\left(3^{\circ} \mathrm{C}\right)$, Red box: warm shared incubation temperature $\left(8^{\circ} \mathrm{C}\right)$ between the two species

was maximal but with opposite effects at $8{ }^{\circ} \mathrm{C}$ (stimulation of state $\mathrm{IV}^{+}$above controls) and $16{ }^{\circ} \mathrm{C}$ (depression of OXPHOS below controls at $16^{\circ} \mathrm{C}$ ).

OXPHOS coupling efficiency in Polar cod under control $\mathrm{PCO}_{2}$ was maximal in the group incubated to $3{ }^{\circ} \mathrm{C}(0.82 \pm$ 0.02 ), and decreased at $8{ }^{\circ} \mathrm{C}$ to values comparable to the $0{ }^{\circ} \mathrm{C}$ group (control $\mathrm{PCO}_{2}: 0.61 \pm 0.03$, high $\mathrm{PCO}_{2}$ : $0.58 \pm 0.05)$, mainly because of increased State $\mathrm{IV}^{+}$at $8{ }^{\circ} \mathrm{C}$ (Fig. 2, 3 and 4). In NEAC (Fig. 4b), the OXPHOS coupling efficiency was maximal at $8{ }^{\circ} \mathrm{C}$ and control $\mathrm{PCO}_{2}(0.81 \pm 0.02)$ and minimal at $16{ }^{\circ} \mathrm{C}$ $(0.64 \pm 0.06)$. In the groups incubated under high $\mathrm{PCO}_{2}$, the maximum of OXPHOS coupling efficiency fell to $3{ }^{\circ} \mathrm{C}(0.77 \pm 0.03)$ and reached its minimum at $8{ }^{\circ} \mathrm{C}(0.46 \pm 0.08)$ to rise again at $12{ }^{\circ} \mathrm{C}$ and $16{ }^{\circ} \mathrm{C}$ $(0.58 \pm 0.05$ and $0.56 \pm 0.05$, respectively). However, these changes in OXPHOS coupling efficiency were not significant (control $P \mathrm{CO}_{2}: \mathrm{F}=5.27 ; p=0.82$, high
$\mathrm{PCO}_{2}: \mathrm{F}=9.7886, p=0.072$ ). At $8{ }^{\circ} \mathrm{C}$, the OXPHOS coupling efficiency was significantly lower under high $\mathrm{PCO}_{2}$ than in the control $P \mathrm{PO}_{2}$ group $(p=0.003)$. Comparing the OXPHOS coupling efficiency between the two species, NEAC and Polar cod showed similar values in the $3{ }^{\circ} \mathrm{C} /$ control $\mathrm{PCO}_{2}$ group (Fig. 4 blue box) and at $8{ }^{\circ} \mathrm{C} /$ high $P C_{2}(p>0.05$, Fig. 4 red box $)$, while the coupling efficiency was higher in NEAC incubated at $8{ }^{\circ} \mathrm{C} /$ control $P C_{2}$ than in Polar cod incubated under the same conditions $(p<0.001$, Fig. 4 red box).

The thermal sensitivity of Complex IV also differed between the two species (Fig. 5). In Polar cod, Complex IV capacity rose from 0 to $6{ }^{\circ} \mathrm{C}$ (control $\mathrm{PCO}_{2}$ : $\mathrm{F}=67.29, p<0.001)$ and decreased between $6{ }^{\circ} \mathrm{C}$ and $8{ }^{\circ} \mathrm{C}$ (control $\mathrm{PCO}_{2}: p<0.001$ ). This trajectory was only present as a non-significant trend in the groups incubated under high $P \mathrm{CO}_{2}(\mathrm{~F}=3.88, p=0.10)$ because of the non-significant decrease of the mean
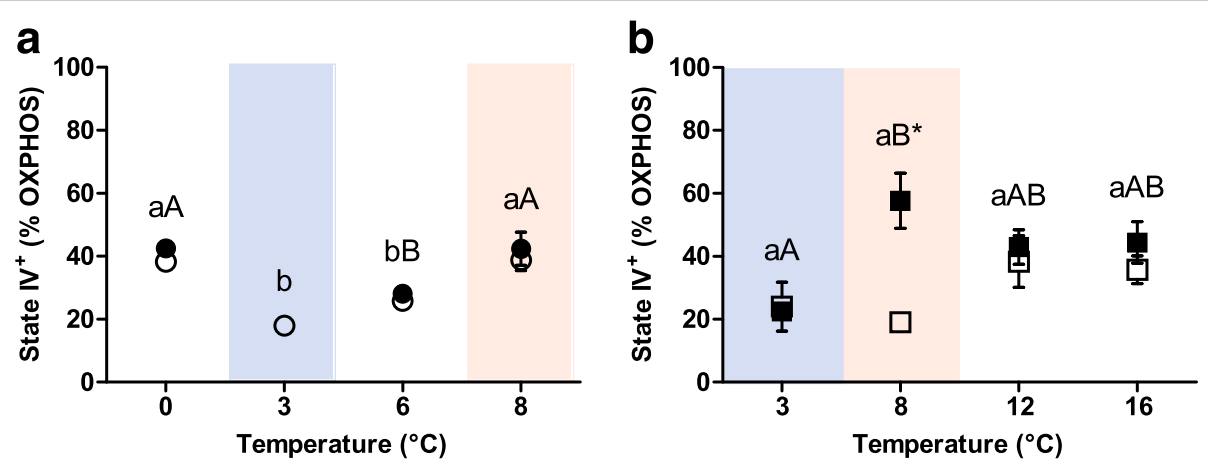

Fig. 3 Percentage of oxygen consumed by State $\mathrm{IV}^{+}$in relation to OXPHOS in permeabilised heart muscle fibres of Polar cod ( $B$. saida, panel a) and NEAC ( $G$. morhua, panel b). Different letters within the panels indicate significant differences $(p<0.05)$ between temperature treatments; lower case letters: control $\mathrm{PCO}_{2}(400 \mu \mathrm{\mu tm})$, upper case letters: high $\mathrm{PCO}_{2}(1170 \mu \mathrm{atm})$, ${ }^{*}$ indicates significant differences $(p<0.05)$ between $\mathrm{CO}_{2}$ groups at the same temperature. All values are reported as means \pm S.E.M. (for $n$ refer to Table 1). Open symbols: $\mathrm{Control} P \mathrm{CO}_{2}(400 \mu \mathrm{tatm})$, filled symbols: high $\mathrm{PCO}_{2}(1170 \mu \mathrm{atm})$. Circles: Polar cod, Squares: NEAC. Blue box: cold shared incubation temperature $\left(3^{\circ} \mathrm{C}\right)$, Red box: warm shared incubation temperature $\left(8^{\circ} \mathrm{C}\right)$ between the two species 

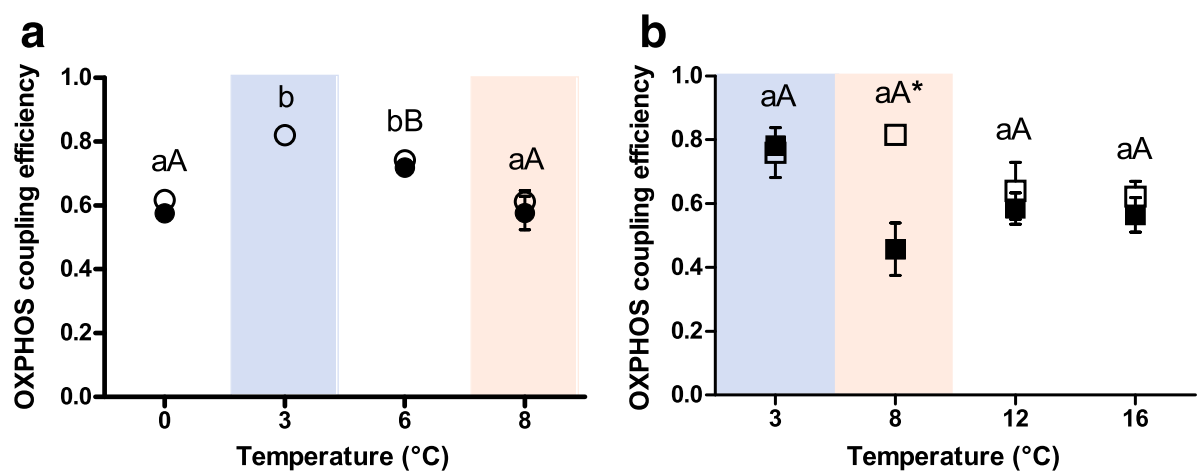

Fig. 4 OXPHOS coupling efficiency in permeabilised heart muscle fibres of (a) Polar cod (B. saida) and (b) NEAC (G. morhua). Different letters within panels indicate significant differences $(p<0.05)$ between temperature treatments; lower case letters: control $P \mathrm{CO}_{2}(400 \mu a t m)$, upper case letters: high $\mathrm{PCO}_{2}(1170 \mu \mathrm{atm})$, * indicates significant differences $(p<0.05)$ between $\mathrm{CO}_{2}$ groups at the same temperature. All values are reported

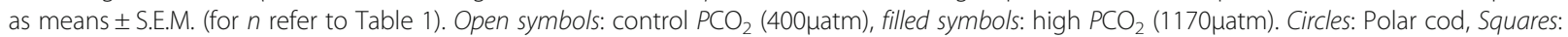
NEAC. Blue box: cold shared incubation temperature $\left(3^{\circ} \mathrm{C}\right)$, Red box: warm shared incubation temperature $\left(8^{\circ} \mathrm{C}\right)$ between the two species

capacity of Complex IV at $6{ }^{\circ} \mathrm{C} /$ high $\mathrm{PCO}_{2}$ compared to control $\mathrm{PCO}_{2}$ at the same temperature $(p=0.09)$. In NEAC, Complex IV capacity increased with increasing temperatures in the groups incubated under control $P \mathrm{PO}_{2}$ $(\mathrm{F}=3.25, p=0.05)$, but not in the groups incubated under high $\mathrm{PCO}_{2}(\mathrm{~F}=2.18, p=0.12)$. At $16{ }^{\circ} \mathrm{C}$, the capacity of NEAC Complex IV was lower under high $\mathrm{PCO}_{2}(p=0.099)$ than under control $\mathrm{PCO}_{2}$. Comparing the two species, the capacity of Complex IV was similar (non-significant differences) in all shared treatments $\left(3{ }^{\circ} \mathrm{C} /\right.$ control $\mathrm{CO}_{2}, 8{ }^{\circ} \mathrm{C} /$ control $\mathrm{CO}_{2}$ and $8{ }^{\circ} \mathrm{C} /$ high $\mathrm{CO}_{2}: p>0.05$, Fig. 5 blue and red boxes).

\section{Discussion}

Our study shows differences in mitochondrial metabolism between a cold-adapted Arctic and a cold-acclimated subArctic fish from the same area, potentially leading to differences in acclimation capacities to ocean acidification and warming.

Mitochondria from permeabilised heart fibres appeared to be affected mainly by the incubation temperature while high levels of $\mathrm{CO}_{2}$ significantly affected mitochondrial respiration only in NEAC (Gadus morhua) and mainly at the highest investigated temperature $\left(16^{\circ} \mathrm{C}\right)$. NEAC OXPHOS and Complex IV capacities decreased under elevated $\mathrm{CO}_{2}$ at high temperature, although the latter only as non-significant trend. This suggests that the noxious effects of high $\mathrm{PCO}_{2}$ are stronger at the upper end of the thermal window and might affect the heat tolerance of NEAC [2, 17]. Furthermore, proton leak at $8{ }^{\circ} \mathrm{C}$ was higher in the group incubated under high $\mathrm{PCO}_{2}$ than in the control $P \mathrm{CO}_{2}$ group, indicating that overall mitochondrial efficiency might be affected through alterations of membrane characteristics. Elevated $P \mathrm{CO}_{2}$ is reported to inhibit Citrate Synthase and
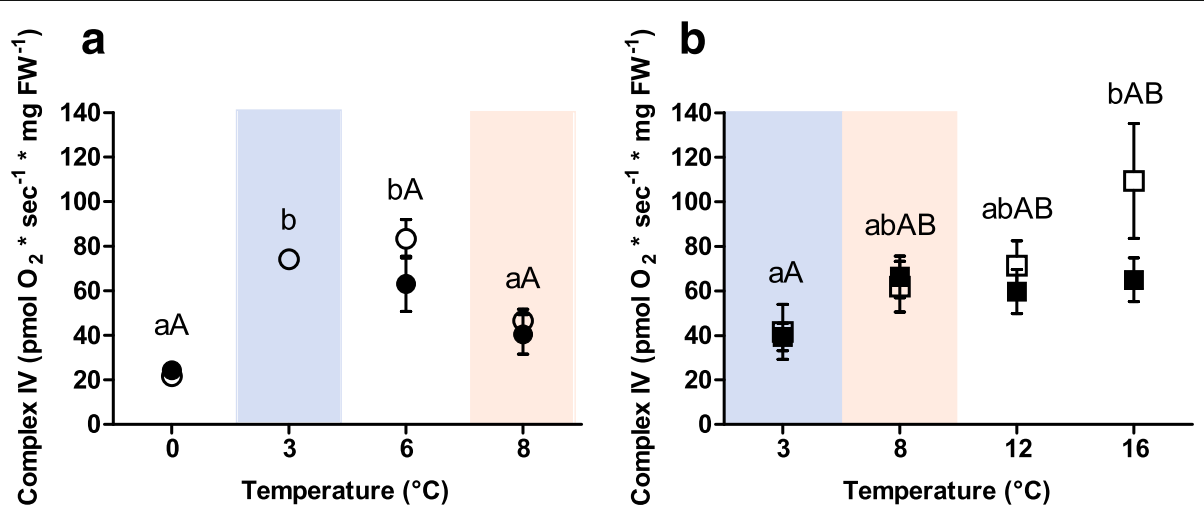

Fig. 5 Complex IV (Cytochrome c Oxidase) capacity. Panel a: permeabilised heart muscle fibres of Polar cod (B. saida). Panel b: permeabilised heart muscle fibres of NEAC (G. morhua). Different letters within the panels indicate significant differences $(p<0.05)$ between temperature treatments; lower case letters: control $P \mathrm{CO}_{2}(400 \mu \mathrm{atm})$, upper case letters: high $P \mathrm{CO}_{2}(1170 \mu \mathrm{utm})$. All values are reported as means \pm S.E.M. (for $n$

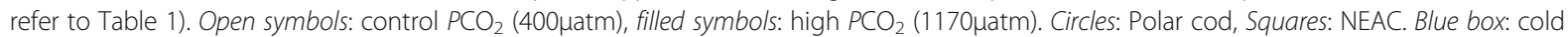
shared incubation temperature $\left(3^{\circ} \mathrm{C}\right)$, Red box: warm shared incubation temperature $\left(8^{\circ} \mathrm{C}\right)$ between the two species 
Complex II in mammals and fish [40, 72, 73] with subsequent stimulation of the mitochondrial anaplerotic pathways to overcome this inhibition [40, 74]. The difference in sensitivity of the two species to elevated levels of $\mathrm{CO}_{2}$ could be related to differences in preferential metabolic pathways, with Polar cod (Boreogadus saida) relying more than NEAC on anaplerotic pathways that feed directly into Complex I such as the oxidation of glutamate, pyruvate or palmitoyl carnitine $[40,73]$. Further investigation, especially at the genetic level is needed. Furthermore, it is still unknown whether and to what extent elevated $\mathrm{PCO}_{2}$ might alter the membrane characteristics and contribute to proton leak.

In Polar cod, OXPHOS of the groups incubated at 3-6-8 ${ }^{\circ} \mathrm{C}$ was higher at the respective incubation temperature than $\mathrm{OXPHOS}$ of the $0{ }^{\circ} \mathrm{C}$ treatments while the OXPHOS coupling efficiency was highest in the $3{ }^{\circ} \mathrm{C}$ group and lowest in the 0 and $8{ }^{\circ} \mathrm{C}$ groups. This indicates an optimum temperature for ATP production efficiency between 3 and $6{ }^{\circ} \mathrm{C}$. At lower and higher temperatures, the increased proton leak in relation to OXPHOS created a less favourable ratio between ATP produced and oxygen consumed. These findings match those by Drost et al. [75], where heart rate of acutely warmed Polar cod increased until a first Arrhenius breakpoint at $3{ }^{\circ} \mathrm{C}$. Heart rate still increased further but at a lower rate until $8{ }^{\circ} \mathrm{C}$, passing a second break temperature. In our study, $8{ }^{\circ} \mathrm{C}$ corresponds to the highest rate of proton leak, and lowest Complex IV capacity, implying a direct participation of mitochondria in the thermal responses of the heart. The close similarity between the data from the acute study of Drost et al. [75], our 4-months incubation study and a study on behavioural thermal preference from Schurmann and Christiansen [76] indicates preferred temperatures of $3-6{ }^{\circ} \mathrm{C}$ within a thermal gradient from 0 to $8{ }^{\circ} \mathrm{C}$ for Polar cod, suggesting that Polar cod have only limited abilities to acclimate to higher temperatures.

In contrast, NEAC OXPHOS continued to increase with long-term incubation temperatures to even above those experienced within the natural habitat. This appears to occur without compromising OXPHOS coupling efficiency and reveals a higher acclimation potential than Polar cod, in line with the overall distribution area of Atlantic cod from temperate to (sub-) Arctic waters. This apparent plasticity is in line with the findings by Zittier et al. [77] in which NEAC specimens acclimated to $15{ }^{\circ} \mathrm{C}$ displayed critical temperatures (Tc, defined as the onset of the anaerobic metabolism, cf. Frederich \& Pörtner [78]) about $10{ }^{\circ} \mathrm{C}$ higher than specimens kept at ambient temperature $\left(4{ }^{\circ} \mathrm{C}\right)$. In Polar cod, the high proton leak at $8{ }^{\circ} \mathrm{C}$ is the main cause of reduced mitochondrial efficiency (OXPHOS coupling efficiency). This increase in proton leak can be caused by loss of membrane integrity in response to changes in membrane fluidity $[7,79]$. In a previous study, Martinez et al. [80] found increased proton permeability of the inner mitochondrial membrane of the Antarctic silverfish Pleuragramma antarcticum after warming. In addition, Strobel et al. [40] found that this may be due to an unchanged saturation index of the mitochondrial membrane, observed in liver of the Antarctic Notothenia rossii after warm acclimation. These findings suggest a limited ability of Antarctic stenothermal fish to acclimate to temperature changes. Similar patterns may constrain acclimation of cold-adapted Arctic fish. The decreased capacity of Complex IV at $8{ }^{\circ} \mathrm{C}$ in Polar cod implies that the interactions between the inner membrane and embedded enzymes may also be affected by high temperatures [80, 81]. In NEAC, proton leak was lower than in Polar cod and reached 40\% of OXPHOS at $12{ }^{\circ} \mathrm{C}$, while in Polar cod the same relative values were found at $8{ }^{\circ} \mathrm{C}$ under control $P \mathrm{CO}_{2}$. A strong thermal response of proton leak may reflect high temperature sensitivity of the organism [52, 82-84], and thus a higher baseline proton leak combined with its steeper increase upon warming may point towards a stronger degree of cold adaptation in Polar cod.

The findings in this study contrast earlier results obtained in isolated mitochondrial suspensions where mitochondria remained fully functional beyond whole organism heat limits $[82,85]$. The present findings suggest that mitochondria may display wider thermal limits in suspensions than when embedded in permeabilised fibres. Mitochondria in permeabilised fibres may still interact with other cellular organelles and are thus integrated into a more complex system than are isolated mitochondria. These considerations suggest that thermal tolerance is more constrained in permeabilized fibres than in isolated mitochondria. Such findings may thus be in line with the assumed narrowing of thermal windows once molecular and mitochondrial functions are integrated into larger units up to whole organism [86]. While the experiment was carried out at non-limiting $\mathrm{PO}_{2}$ in the media $\left(>100 \mathrm{nmol} \mathrm{ml}^{-1}\right)$ [87], diffusion gradients of oxygen and/or other substances within the permeabilised cardiac fibres may cause this hierarchy in thermal constraints. In a study on growth, mortality and standard metabolic rates (SMR) of the same Polar cod and NEAC as examined in this study, Kunz et al. [61] found higher SMR in Polar cod than in NEAC at the same incubation temperatures. This is mirrored in the mitochondrial respiration presented in this study, where OXPHOS capacity in Polar cod was larger than in NEAC at both 3 and $8{ }^{\circ} \mathrm{C}$. In Polar cod, the SMR of the 3 and $6{ }^{\circ} \mathrm{C}$ groups were lower than in the groups incubated at $8{ }^{\circ} \mathrm{C}$, which is mirrored in the pattern of cardiac State $\mathrm{IV}^{+}$respiration. At $8{ }^{\circ} \mathrm{C}$ the OXPHOS coupling 
efficiency (i.e. ATP production efficiency) decreased as State $\mathrm{IV}^{+}$increased and the capacity of Complex IV decreased. Maybe these findings indicate decreased cardiac mitochondrial efficiency that may limit cardiac function and promote heart failure, which is consistent with a drop in cardiac function [75] and the onset of heart failure in Polar cod at $8{ }^{\circ} \mathrm{C}$. At this temperature, oxygen demand and mortality increased, and growth decreased in this species [61]. In fact, the estimated decrease in ATP production efficiency at $8{ }^{\circ} \mathrm{C}$ was paralleled by a reduced feed conversion efficiency and concomitant increase in SMR. This likely indicates a shift in energy allocation due to an impaired balance between energy production and demand, e.g. due to increased mitochondrial proton leak (see [88] for review). According to these findings, $8{ }^{\circ} \mathrm{C}$ is close to the long-term upper thermal tolerance limit for the Svalbard population of Polar cod, which is again in line with the observed increased mortality [61].

In NEAC, the parallel rise of whole organism SMR and cardiac fibre OXPHOS and the parallel decrease of OXPHOS and SMR at high $\mathrm{PCO}_{2}$ compared to controls at $16{ }^{\circ} \mathrm{C}$ indicates that cardiac mitochondrial function is adjusted to the level of whole animal energy demand at different incubation temperatures and that the effects of high $\mathrm{PCO}_{2}$ are greatest close to the upper thermal limit. Thermal constraints setting in at whole animal level may again relate to the thermal sensitivity of cardiac mitochondrial function $[28,29,32,33]$. The fact that first performance limitations are observed in the $16{ }^{\circ} \mathrm{C} /$ high $\mathrm{PCO}_{2}$ incubation may not be of direct relevance for the Svalbard stock of NEAC over the next century, but marks a potential southern distribution limit for the Barents Sea and Norwegian Sea.

Polar cod is a cold adapted species and the constraint on cardiac mitochondrial metabolism at $8{ }^{\circ} \mathrm{C}$, concomitant with increased mortality indicates that the animal's thermal window matches its current habitat temperature range. In contrast, adult NEAC show the ability to broaden their thermal window beyond the present subArctic habitat temperatures (see above). Because of the habitat temperature range of the two species is similarly wide but shifted to lower temperatures in Polar cod, combined with the high metabolic baseline cost (SMR) of Polar cod the two species may be classified as coldadapted (Polar cod) or cold-acclimated (NEAC) eurytherms. NEAC appear to be much more plastic than Polar cod, thus, Polar cod may be more vulnerable to future ocean conditions than NEAC.

\section{Conclusions}

Future ocean acidification and warming may impair cardiac mitochondrial function of Polar cod (Boreogadus saida) and Northeast Arctic cod (NEAC, Gadus morhua) in somewhat different ways. In Polar cod, high temperature $\left(8^{\circ} \mathrm{C}\right)$ increases proton leak and thereby decreases ATP production efficiency, while high $\mathrm{CO}_{2}$ levels did not have a significant effect. In NEAC, mitochondrial respiration remained functional at higher temperatures, but capacity was depressed by the combination of high temperature and high $\mathrm{PCO}_{2}$. Furthermore, in $\mathrm{NEAC}$, incubation temperature leads to variable mitochondrial response patterns under elevated $P \mathrm{CO}_{2}$. The causes of the different responses to elevated $P \mathrm{CO}_{2}$ in the heart of these two species remain to be identified, for example, the role of anaplerotic pathways and their regulation should be further investigated.

As a result of the degree of cold adaptation, Polar cod display high metabolic maintenance costs (indicating that it is cold-eurythermal) and low acclimation capacity, while NEAC is cold acclimated and benefits from a lower rate of metabolism and a higher plasticity to acclimate to increasing temperature. As a consequence, mitochondrial function of NEAC hearts may be less constrained by rising temperatures than Polar cod, indicating that NEAC could outperform and possibly replace Polar cod in the waters around Svalbard if ocean warming and acidification further increase towards the conditions predicted for the end of the century $\left(8{ }^{\circ} \mathrm{C}\right.$ and $\left.1170 \mu a t m \mathrm{PCO}_{2}\right)$. Since Polar cod has a key role in Arctic ecosystems [48], temperature driven changes in the distribution of this species can be an important component in the impacts of climate change on Arctic ocean ecosystems.

\section{Acknowledgements}

We thank Silvia Hardenberg, Nils Koschnick, Timo Hirse, Isabel Ketelsen and Heidrun Windisch for their support during the incubation and sampling procedures. We acknowledge the project Polarisation (Norwegian Research Council, 214184/F20) for providing Polar cod specimens and the crews of RV Heincke (HE 408) and RV Helmer Hanssen for the animal collection.

\section{Funding}

This project was funded by the German Federal Ministry of Education and Research (BMBF, FKZ 03F0655B) within the research program BIOACID phase $\|$ and by the PACES program of AWI.

\section{Availability of data and materials \\ The datasets analysed during the current study and the data regarding the incubation set-up are available from the Open Access library PANGAEA (www.pangaea.de; https://doi.pangaea.de/10.1594/PANGAEA.866369; https:// doi.pangaea.de/10.1594/PANGAEA.873536).}

\section{Authors' contributions}

EL, KK, MS, DS, HOP and FCM designed the study. EL, KK, MS carried out the animal incubations. EL performed the experiment on cardiac mitochondria and all data analyses and interpreted the results together with FCM. EL and FCM drafted the manuscript, KK MS DS and HOP contributed to writing the manuscript. All authors read and approved the final manuscript.

Competing interests

The authors declare that they have no competing interests.

Consent for publication

Not applicable. 


\section{Ethics approval}

Experiments were conducted in accordance with the ethical permission number AZ522-27-22/02-00 (113) released by the Senator for Healthcare, Bahnhofsplatz 29, 28195 Bremen on February 21 ${ }^{\text {st }}, 2013$ and valid until February $21^{\text {st }}, 2017$

\section{Publisher's Note}

Springer Nature remains neutral with regard to jurisdictional claims in published maps and institutional affiliations.

\section{Author details}

'Alfred Wegener Institute, Helmholtz Centre for Polar and Marine Research, Integrative Ecophysiology, Am Handelshafen 12, D-27570 Bremerhaven, Germany. ${ }^{2}$ University of Bremen, Fachbereich 2, NW 2/Leobener Strasse, D-28359 Bremen, Germany. ${ }^{3}$ Alfred Wegener Institute, Helmholtz Centre for Polar and Marine Research, Bentho-Pelagic Processes, Am Alten Hafen 26, D-27568 Bremerhaven, Germany.

\section{Received: 14 February 2017 Accepted: 30 March 2017} Published online: 14 April 2017

\section{References}

1. Renaud PE, Berge J, Varpe $\varnothing$, Lønne OJ, Nahrgang J, Ottesen C, Hallanger I. Is the poleward expansion by Atlantic cod and haddock threatening native polar cod, Boreogadus saida? Polar Biol. 2012;35:401-12.

2. Pörtner HO, Farrell AP. Physiology and climate change. Science. 2008;322:690-2.

3. Pörtner $\mathrm{HO}$, Knust R. Climate change affects marine fishes through the oxygen limitation of thermal tolerance. Science. 2007;315:95-7.

4. Parmesan C. Ecological and evolutionary responses to recent climate change. Annu Rev Ecol Evol S. 2006;37:637-69.

5. Poloczanska ES, Brown CJ, Sydeman WJ, Kiessling W, Schoeman DS, Moore PJ, Bander K, Bruno JF, Buckley LB, Burrows MT, Duarte CM, Halpern BS, Holding J, Kappel CV, O'Connor MI, Pandolfi JM, Parmesan C, Schwing F, Thompson SA, Richardson AJ. Global imprint of climate change on marine life. Nat Clim Change. 2013. doi:10.1038/nclimate1958.

6. Fossheim M, Primicerio $R$, Johannesen $E$, Ingvaldsen RB, Aschan MM, Dolgov A. Recent warming leads to a rapid borealization of fish communities in the Arctic. Nat Clim Change. 2015. doi:10.1038/NCLIMATE2647.

7. Hochachka PW, Somero GN. Biochemical adaptation: mechanism and process in physiological evolution. Oxford: Oxford University Press; 2002

8. Guderley H, St-Pierre J. Going with the flow or life in the fast lane: contrasting mitochondrial responses to thermal change. J Exp Biol. 2002;205:2237-49.

9. Caldeira K, Wickett ME. Anthropogenic carbon and ocean pH. Nature. 2003;425:365

10. Di Santo V. Ocean acidification exacerbates the impact of global warming on embryonic little skate, Leucoraja erinacea (Mitchill). J Exp Mar Biol Ecol. 2014. doi:10.1016/j.jembe.2014.11.006.

11. Dixson DL, Abrego D, Hay ME. Chemically mediated behavior of recruiting corals and fishes: a tipping point that may limit reef recovery. Science. 2014;345:892-7.

12. Heuer RM, Grosell M. Physiological impacts of elevated carbon dioxide and ocean acidification on fish. Am J Physiol Regul Integr Compa Physiol. 2014;307:R1061-84.

13. Wittmann AC, Pörtner HO. Sensitivities of extant animal taxa to ocean acidification. Nat Clim Change. 2013;3:995-1001.

14. Przeslawski R, Byrne M, Mellin C. A review and meta-analysis of the effects of multiple abiotic stressors on marine embryos and larvae. Glob Chang Biol. 2015;21:2122-40.

15. Hoegh-Guldberg, Bruno JF. The Impact of Climate Change on the World's Marine Ecosystems. Science. 2010. doi: 10.1126/science.1189930.

16. Hutchins DA, Mulholland MR, Fu F-X. Nutrient cycles and marine microbes in a CO2-enriched ocean. Oceanography. 2009;22:128-45.

17. Pörtner HO. Oxygen-and capacity-limitation of thermal tolerance: a matrix for integrating climate-related stressor effects in marine ecosystems. J Exp Biol. 2010;213:881-93.

18. Metzger R, Sartoris FJ, Langenbuch M, Pörtner HO. Influence of elevated $\mathrm{CO} 2$ concentrations on thermal tolerance of the edible crab Cancer pagurus. J Therm Biol. 2007;32:144-51.
19. Pörtner HO. Integrating climate-related stressor effects on marine organisms: unifying principles linking molecule to ecosystem-level changes. Mar Ecol Prog Ser. 2012;470:273-90.

20. Flynn EE, Bjelde BE, Miller NA, Todgham AE. Ocean acidification exerts negative effects during warming conditions in a developing Antarctic fish. Conserv Physiol. 2015. doi:https://doi.org/10.1093/conphys/cov033.

21. Pimentel MS, Faleiro F, Dionisio G, Repolho T, Pousao-Ferreira P, Machado J, Rosa R. Defective skeletogenesis and oversized otoliths in fish early stages in a changing ocean. J Exp Biol. 2014;217:2062-70.

22. Hofmann GE, Todgham AE. Living in the now: physiological mechanisms to tolerate a rapidly changing environment. Annu Rev Physiol. 2010;72:127-45.

23. Abele D, Puntarulo S. Formation of reactive species and induction of antioxidant defence systems in polar and temperate marine invertebrates and fish. Comp Biochem Physiol Part A. 2004;138:405-15.

24. Mueller IA, Grim JM, Beers JM, Crockett EL, O'Brien KM. Inter-relationship between mitochondrial function and susceptibility to oxidative stress in red- and whiteblooded Antarctic notothenioid fishes. J Exp Biol. 2011;214:3732-41.

25. Stillmann JH. Acclimation Capacity Underlies Susceptibility to Climate Change. Science. 2003. doi:10.1126/science.1083073.

26. Farrell AP. Cardiorespiratory performance during prolonged swimming tests with salmonids: a perspective on temperature effects and potential analytical pitfalls. Phil Trans R Soc B. 2007. doi:10.1098/rstb.2007.2111.

27. Ekström A, Brijs J, Clark TD, Gräns A, Jutfelt F, Sandblom E. Cardiac oxygen limitation during an acute thermal challenge in the European perch: Effects of chronic environmental warming and experimental hyperoxia. Am J Physiol Reg Int Comp Physiol. 2016. doi:10.1152/ajpregu.00530.2015.

28. Hilton Z, Clements KD, Hickey AJ. Temperature sensitivity of cardiac mitochondria in intertidal and subtidal triplefin fishes. J Comp Physiol B. 2010;180:979-90.

29. Iftikar Fl, Hickey AJR. Do Mitochondria Limit Hot Fish Hearts? Understanding the Role of Mitochondrial Function with Heat Stress in Notolabrus celidotus. PLoS ONE. 2013. doi:10.1371/journal.pone.0064120.

30. Strobel A, Bennecke S, Leo E, Mintenbeck K, Pörtner HO, Mark FC. Metabolic shifts in the Antarctic fish Notothenia rossii in response to rising temperature and $\mathrm{PCO}_{2}$. Front Zool. 2012;9:28.

31. Rodnick KJ, Gamperl AK, Nash GW, Syme DA. 2014. Temperature and sex dependent effects on cardiac mitochondrial metabolism in Atlantic cod (Gadus morhua L.). J Therm Biol. 2014:44:110-8.

32. Iftikar Fl, MacDonald JR, Baker DW, Renshaw GMC, Hickey AJR. Could thermal sensitivity of mitochondria determine species distributions in a changing climate? J Exp Biol. 2014. doi:10.1242/jeb.098798.

33. Iftikar Fl, Morash AJ, Cook DG, Herbert NA, Hickey AJR. Temperature acclimation of mitochondrial function from the hearts of a temperate wrasse (Notolabrus celidotus). Comp Biochem Phys A. 2015. doi: 10.1016/j. cbpa.2015.01.017.

34. Brand MD. The efficiency and plasticity of mitochondrial energy transduction. Biochem Soc Trans. 2005. doi:10.1042/BST20050897.

35. Brand MD, Nicholls DG. Assessing mitochondrial dysfunction in cells Biochem J. 2011. doi:10.1042/BJ20110162.

36. Vinogradov AD, Grivenn VG. The mitochondrial complex I: progress in understanding of catalytic properties. IUBMB Life. 2001;52:129-34

37. Clarke A, Johnston NM. Scaling of metabolic rate with body mass and temperature in teleost fish.J Anim Ecol. 1999;68:893-905.

38. Michaelidis B, Spring A, Pörtner HO. Effects of long-term acclimation to environmental hypercapnia on extracellular acid-base status and metabolic capacity in Mediterranean fish Sparus aurata. Mar Biol. 2007;150:1417-29.

39. Deigweiher K, Koschnick N, Pörtner HO, Lucassen M. Acclimation of ion regulatory capacities in gills of marine fish under environmental hypercapnia. Am J Physiol Reg Int Comp Physiol. 2008. 10.1152/ajpregu. 90403.2008

40. Strobel A, Graeve M, Pörtner HO, Mark FC. Mitochondrial acclimation capacities to ocean warming and acidification are limited in the Antarctic nototheniid fish, Notothenia rossii and Lepidonotothen squamifrons. PLoS ONE. 2013. doi:10.1371/journal.pone.0068865.

41. Stapp LS, Kreiss CM, Pörtner HO, Lannig G. Differential impacts of elevated $\mathrm{CO}_{2}$ and acidosis on the energy budget of gill and liver cells from Atlantic cod, Gadus morhua. Comp Biochem Phys A. 2015. doi:10.1016/j.cbpa.2015.05.009.

42. Harvey BP, Gwynn-Jones D, Moore PJ. Meta-analysis reveals complex marine biological responses to the interactive effects of ocean acidification and warming. Ecol Evol. 2013. doi: 10.1002/ece3.516. 
43. Stillman JH, Paganini AW. Biochemical adaptation to ocean acidification. J Exp Biol. 2015. doi:10.1242/jeb.115584.

44. Drinkwater K. Comparison of the response of Atlantic cod (Gadus morhua) in the high-latitude regions of the North Atlantic during the warm periods of the 1920s-1960s and the 1990s-2000s. Deep-Sea Res. 2009;Pt II 56:2087-96.

45. Kortsch S, Primicerio R, Fossheim M, Dolgov AV, Aschan M. Climate change alters the structure of arctic marine food webs due to poleward shifts of boreal generalists. Proc R Soc B. 2015;282:20151546.

46. Christiansen JS, Bonsdorff E, Byrkjedal I, Fevolden S-E, Karamushko OV, Lynghammar A, Mecklenburg CW, Møller PDR, Nielsen J, Nordström MC, Præbel K, Wienerroither RM. Novel biodiversity baselines outpace models of fish distribution in Arctic waters. Sci Nat. 2016. doi:10.1007/s00114016-1332-9.

47. Olsen E, Aanes S, Mehl S, Holst JC, Aglen A, Gjøsæter H. Cod, haddock, saithe, herring, and capelin in the Barents Sea and adjacent waters: a review of the biological value of the area. ICES J Mar Sci. 2010;67:87-101.

48. Laurel BJ, Spencer M, Iseri P, Copeman LA. Temperature-dependent growth and behavior of juvenile Arctic cod (Boreogadus saida) and co-occurring North Pacific gadids. Polar Biol. 2015. doi: 10.1007/s00300-015-1761-5.

49. Mark FC, Rohardt G. Continuous thermosalinograph oceanography along HEINCKE cruise track HE451-1. Alfred Wegener Institute, Helmholtz Center for Polar and Marine Research, Bremerhaven. 2016. doi:10.1594/ PANGAEA.863418.

50. Michalsen K, Johansen T, Subbey S, Beck A. Linking tagging technology and molecular genetics to gain insight in the spatial dynamics of two stocks of cod in Northeast Atlantic waters. ICES J Mar Sci. 2014. doi:10. 1093/icesjms/fsu083.

51. Johnston IA, Calvo J, Guderley YH. Latitudinal variation in the abundance and oxidative capacities of muscle mitochondria in perciform fishes. J Exp Biol. 1998;201:1-12.

52. Pörtner HO, van Dijk PLM, Hardewig I, Sommer A. Levels of metabolic cold adaptation: tradeoffs in eurythermal and stenothermal ectotherms. In: Davison W, Williams HC, editors. Antarctic ecosystems: models for wider ecological understanding. Christchurch: Caxton; 2000. p. 109-22.

53. Pörtner HO, Bock C, Knust R, Lannig G, Lucassen M, Mark FC, Sartoris FJ. Cod and climate in a latitudinal cline: physiological analyses of climate effects in marine fishes. Climate Res. 2008;37:253-70.

54. Pörtner HO. Climate dependent evolution of Antarctic ectotherms: an integrative analysis (EASIZ, SCAR). Deep-Sea Res Pt II. 2006;53:1071-104.

55. Blier PU, Lemieux H, Pichaud N. Holding our breath in our modern world: will mitochondria keep the pace with climate changes? Can J Zool. 2014;92: 591-601.

56. Lucassen M, Koschnick N, Eckerle LG, Pörtner HO. Mitochondrial mechanisms of cold adaptation in cod (Gadus morhua L.) populations from different climatic zones. J Exp Biol. 2006;209:2462-71.

57. Pörtner HO, Karl DM, Boyd PW, Cheung WWL, Lluch-Cota SE, Nojiri Y, Schmidt DN, Zavialov PO. Ocean systems. In: Field CB, Barros VR, Dokken DJ, Mach KJ, Mastrandrea MD, Bilir TE, Chatterjee M, Ebi KL, Estrada YO, Genova RC, Girma B, Kissel ES, Levy AN, MacCracken S, Mastrandrea PR, White LL, editors. Climate Change 2014: Impacts, Adaptation, and Vulnerability. Part A: Global and Sectoral Aspects. Contribution of Working Group II to the Fifth Assessment Report of the Intergovernmental Panel on Climate Change. Cambridge and New York: Cambridge University Press; 2014. p. 411-84.

58. Natori $\mathrm{H}$. The property and contraction process of isolated myofibrils. Jikei Med J. 1954;1:119-26.

59. Saida K, Nonomura Y. Characteristics of $\mathrm{Ca} 2+-$ and Mg2 + -induced tension development in chemically skinned smooth muscle fibers. J Gen Physiol. 1978;72(1):1-14.

60. Pesta D, Gnaiger E. High-resolution respirometry. OXPHOS protocols for human cells and permeabilized fibres from small biopsies of human muscle. Methods Mol Biol. 2012;810:25-58.

61. Kunz KL, Frickenhaus S, Hardenberg S, Johansen T, Leo E, Pörtner HO, Schmidt M, Windisch HS, Knust R, Mark FC. New encounters in Arctic waters: a comparison of metabolism and performance of polar cod (Boreogadus saida) and Atlantic cod (Gadus morhua) under ocean acidification and warming. Polar Biol. 2016. doi: 10. 1007/s00300-016-1932-z

62. Holst JC, McDonald A. FISH-LIFT: a device for sampling live fish with trawls. Fish Res. 2000;48:87-91.

63. Lewis E, Wallace DWR. Program developed for $\mathrm{CO} 2$ system calculations. Carbon Dioxide Information Analysis Center, Oak Ridge National Laboratory, Oak Ridge. 1998; TN. ORNL/CDIAC-105.
64. Mehrbach C, Culberson CH, Hawley JE, Pytkowicz RN. Measurement of the apparent dissociation constants of carbonic acid in seawater at atmospheric pressure. Limnol Oceanogr. 1973;18:897-907.

65. Dickson AG, Millero FJ. A comparison of the equilibrium constants for the dissociation of carbonic acid in seawater media. Deep Sea Res. 1987;34:1733-43.

66. Dickson AG. Standard potential of the reaction: $\mathrm{AgCl}(\mathrm{s})+1 / 2 \mathrm{H}_{2}(\mathrm{~g})=\mathrm{Ag}(\mathrm{s})$ $+\mathrm{HCl}(\mathrm{aq})$, and the standard acidity constant of the ion $\mathrm{HSO}_{4}^{-}$in synthetic sea water from 273.15 to 318.15 K. J Chem Thermodyn. 1990;22:113-27.

67. Schmidt M, Leo E, Kunz KL, Lucassen M Windisch HS, Storch D, Bock C, Pörtner HO, Mark FC. (Table $1+$ Table 2) Time series of seawater carbonate chemistry calculated throughout incubation periods of Boreogadus saida and Gadus morhua during exposure to different $\mathrm{CO} 2$ and temperature conditions. 2016. doi:10.1594/PANGAEA.866369.

68. Leo E, Kunz K, Schmidt M, Storch D, Pörtner HO, Mark FC. Individual mitochondrial functioning parameters from cardiac permeabilised fibers of Polar cod (Boreogadus saida) and Atlantic cod (Gadus morhua) acclimated to ocean acidification and warming. 2017. https://doi.pangaea.de/10.1594/ PANGAEA.873536. Accessed 4 Apr 2017.

69. Gnaiger E, Kuznetsov AV, Schneeberger S, Seiler R, Brandacher G, Steurer W, Margreiter R. Mitochondria in the cold. In: Heldmaier M, Klingenspor M, editors. Life in the Cold. Heidelberg: Springer; 2000. p. 431-42.

70. Gnaiger E, Boushel R, Søndergaard H, Munch-Andersen T, Damsgaard R, Hagen C, Diéz-Sánchez C, Ara I, Wright-Paradis C, Schrauwen P, Hesselink M, Calbet JAL, Christiansen M, Helge JW, Saltin B. Mitochondrial coupling and capacity of oxidative phosphorylation in skeletal muscle of Inuit and Caucasians in the arctic winter. Scand J Med Sci Spor. 2015;25:126-34.

71. R Core Team. R: A language and environment for statistical computing. $R$ Foundation for Statistical Computing, Vienna, Austria. 2015; URL: http:// www.R-project.org/. Accessed 4 Apr 2017.

72. Simpson DP. Regulation of renal citrate metabolism by bicarbonate ion and pH: observations in tissue slices and mitochondria. J Clin Invest. 1967;46:225.

73. Wanders RJA, Meijer AJ, Groen AK, Tager JM. Bicarbonate and the Pathway of Glutamate Oxidation in Isolated Rat-Liver Mitochondria. Eur J Biochem. 1983. doi: 10.1111/J.1432-1033.1983.Tb07455.X.

74. Langenbuch M, Pörtner HO. Energy budget of hepatocytes from Antarctic fish (Pachycara brachycephalum and Lepidonotothen kempi) as a function of ambient CO2: pH-dependent limitations of cellular protein biosynthesis? J Exp Biol. 2003. doi:10.1242/jeb.00620.

75. Drost HE, Carmack EC, Farrell AP. Upper thermal limits of cardiac function for Arctic cod Boreogadus saida, a key food web fish species in the Arctic Ocean. J Fish Biol. 2014;84:1781-92.

76. Schurmann $\mathrm{H}$, Christiansen JS. Behavioral thermoregulation and swimming activity of two Arctic teleosts (subfamily Gadinae)-the polar cod (Boreogadus saida) and the navaga (Eleginus navaga). J Therm Biol. 1994;19:207-12.

77. Zittier Z. Einfluss der Temperatur auf das Wachstum von Fischen unterschiedlicher Entwicklungsstadien. Diploma thesis, Universität Bremen. 2006. hdl:10013/epic.28057.

78. Frederich M, Pörtner HO. Oxygen limitation of thermal tolerance defined by cardiac and ventilatory performance in spider crab, Maja squinado. Am J Physiol Reg Int Comp Physiol. 2000;279:R1531-8.

79. Hazel JR. Thermal adaptation in biological membranes: is homeoviscous adaptation an explanation? Annu Rev Physiol. 1995;57:19-42.

80. Martinez E, Menze MA, Torres JJ. Mitochondrial energetics of benthic and pelagic Antarctic teleosts. Mar Biol. 2013. doi: 10.1007/s00227-013-2273-X.

81. O'Brien J, Dalhoff E, Somero GN. Thermal resistance of mitochondrial respiration: hydrophobic interactions of membrane proteins may limit mitochondrial thermal resistance. Physiol Zool. 1991;64:1509-26.

82. Hardewig I, Peck LS, Pörtner HO. Thermal sensitivity of mitochondrial function in the Antarctic Notothenioid Lepidonotothen nudifrons. J Comp Physiol B. 1999;169:597-604.

83. Salin K, Luquet E, Rey B, Roussel D, Voituron Y. Alteration of mitochondrial efficiency affects oxidative balance, development and growth in frog (Rana temporaria) tadpoles. J Exp Biol. 2012. doi:10.1242/jeb.062745.

84. Salin K, Auer SK, Rey B, Selman C, Metcalfe NB. Variation in the link between oxygen consumption and ATP production, and its relevance for animal performance. Proc. R. Soc. B. 2015. doi: 10.1098/rspb.2015.1028.

85. Weinstein RB, Somero GN. Effects of temperature on mitochondrial function in the Antarctic fish Trematomus bernachii. J Comp Physiol. 1998;168B:190-6. 
86. Pörtner HO. Climate variations and the physiological basis of temperature dependent biogeography: systemic to molecular hierarchy of thermal tolerance in animals. Comp Biochem Phys A. 2002;132:739-61.

87. Gnaiger E. Bioenergetics at low oxygen: dependence of respiration and phosphorylation on oxygen and adenosine diphosphate supply. Resp Physiol. 2001;128:277-97.

88. Pörtner $\mathrm{HO}$, Mark FC, Bock C. Oxygen limited thermal tolerance in fish? Answers obtained by nuclear magnetic resonance techniques. Respir Physiol Neurobiol. 2004;141:243-60.

Submit your next manuscript to BioMed Central and we will help you at every step:

- We accept pre-submission inquiries

- Our selector tool helps you to find the most relevant journal

- We provide round the clock customer support

- Convenient online submission

- Thorough peer review

- Inclusion in PubMed and all major indexing services

- Maximum visibility for your research

Submit your manuscript at www.biomedcentral.com/submit 